\title{
ANALISIS FENOTIP DAN GENETIK AYAM TOLAKI PADA MASA PERTUMBUHAN
}

\section{PHENOTYPE AND GENOTYPE ANALYSES OF TOLAKI CHICKENS ON GROWTH STAGE}

\author{
Rusli Badaruddin*, Jafendi Hasoloan Purba Sidadolog, dan Tri Yuwanta \\ Fakultas Peternakan, Universitas Gadjah Mada, Jl. Fauna No. 3, Bulaksumur, Yogyakarta, 55281
}

\section{INTISARI}

Ayam Tolaki merupakan ayam lokal Konawe, Konawe Selatan, Sulawesi Tenggara. Penelitian ini bertujuan untuk mengetahui dan mempelajari sifat fenotip dan genetik pada pertumbuhan ayam Tolaki. Lima kelompok perkawinan dari 5 ekor pejantan dan 15 ekor induk dengan masing-masing kelompok 1 ekor pejantan dengan 3 ekor induk menghasilkan 144 ekor anak ayam Tolaki yang terdiri dari 78 ekor jantan dan 66 ekor betina. Ayam diberi pakan secara adlibitum. Pengamatan meliputi karakteristik fenotip ayam Tolaki, berupa berat badan umur 0 sampai 12 minggu dan pertambahan berat badan. Data dianalisis dengan variansi Nested design (struktur hierarkis) untuk mendapatkan komponen variansi. Komponen variansi digunakan untuk mengestimasi nilai-nilai genetik (heritabilitas) sifat pertumbuhan ayam Tolaki. Hasil penelitian menunjukkan pertumbuhan ayam jantan lebih cepat dibandingkan ayam betina. Kemampuan sifat pertumbuhan ayam Tolaki berdasarkan komponen variansi jantan, betina dan variansi induk cukup berfluktuasi. Pewarisan sifat pertumbuhan berdasarkan komponen variansi jantan $\left(\hat{\mathrm{h}}_{\mathrm{s}}^{2}\right)$ tinggi pada umur 0 sampai 12 minggu dan bernilai positif.

(Kata kunci: Ayam Tolaki, Fenotip, Genetik, Heritabilitas, dan Pertumbuhan)

\section{ABSTRACT}

Tolaki chicken is a local chicken of Konawe, South Konawe, South-East Sulawesi. This study was aim to identify the phenotype and genotype of Tolaki chickens in the growth stage. The data were collected from 5 of mating groups between 5 roosters and 15 hens. Every group consisted of 1 and 3 head and produced 144 chicks (78 males and 66 females). The feed was given ad-libitum. Data collection included the phenotype characteristic and body weight of 0 until 12 weeks ages. The data were analyzed using ANOVA with Nested (hierarchical structure) design to obtain the components of variance. The components of variance were used for estimating genetic parameters especially the heritability of the growth phase of Tolaki chicken. The results indicated that the growth of male chicken was faster than a rooster chicken. The heritability of growth trait based on the sire variance component $\left(\hat{h}_{s}^{2}\right)$ was high and had positive value at 0 to 12 weeks age.

(Keywords: Chicken Tolaki, Genotype, Growth, Heritability, Phenotypes)

\section{Pendahuluan}

Ayam lokal di Indonesia adalah kekayaan alam yang merupakan aset nasional yang tidak ternilai harganya. Beberapa diantaranya merupakan cikal bakal bagi ayam ras yang dikembangkan di luar negeri. Indonesia dikenal sebagai negara yang memiliki keanekaragaman hayati (biodiversity) yang tinggi termasuk ayam piaraan. Ayam piaraan yang ada sekarang ini diperkirakan berasal dari keturunan ayam hutan merah (Gallus gallus) dan ayam hutan hijau (Gallus varius) (Iswanto, 2005).

Hasil identifikasi perkembangbiakan ayam piaraan atau ayam lokal Indonesia, diketahui terdapat 27 jenis ayam lokal yang memiliki karakteristik penampilan yang khas (Nataamijaya dan Dwiyanto, 1994) dan Anonimus (2008)

\footnotetext{
* Korespondensi (corresponding author):

Telp. +6281245551890

E-mail: rbadaruddin79@yahoo.com
}

melaporkan terdapat lebih kurang 31 galur ayam asli Indonesia.

Ayam Tolaki adalah ayam asli Sulawesi Tenggara yang tersebar di beberapa daerah seperti Kabupaten Konawe dan Konawe Selatan. Namun demikian, informasi karakteristik ayam Tolaki sebagai ayam khas Sulawesi Tenggara belum banyak dilaporkan, baik karakter fenotip maupun genotipnya, termasuk potensi produktivitas dan reproduktivitasnya. Hasil penelitian awal diketahui bahwa ayam Tolaki banyak digunakan sebagai ayam sabungan (Nafiu dan Rusdin, 2007). Sabung ayam Tolaki biasanya diperagakan sebagai bagian dari pertunjukan seni budaya lokal di Sulawesi Tenggara. Sementara Sarwono (2007) menyatakan ayam Tolaki cocok dikembangkan sebagai ayam petelur.

Penelitian yang mempelajari aspek biologis dan genetik pada ayam Tolaki belum dilaksanakan, sehingga data potensi produksi, efisiensi pemeliharaan belum banyak diketahui. Sebagai langkah awal penelitian ini dilakukan untuk mengetahui 
potensi yang dimiliki tentang sifat-sifat fenotip dan genetik ayam Tolaki pada masa pertumbuhan.

\section{Materi dan Metode}

Penelitian ini dilaksanakan selama lima bulan yang bertempat di kandang unggas Jurusan Peternakan, Fakultas Pertanian, Universitas Haluoleo Kendari. Materi penelitian ayam Tolaki jantan dan induk dipilih secara acak dengan umur dan berat yang relatif sama sebanyak 5 ekor pejantan dan 15 ekor induk. Keturunan dari hasil perkawinan tersebut berupa DOC unsexed sebanyak 144 ekor. Pertumbuhan anak ayam tersebut diteliti dan diamati mulai umur 0 sampai umur 12 minggu. Pakan yang digunakan untuk pejantan dan induk adalah pakan yang biasa digunakan di Universitas Haluoleo Kendari dengan komposisi dan kandungan nutrien (Tabel 1). Pakan yang digunakan untuk keturunan ayam Tolaki mulai umur 0 sampai umur 12 minggu disusun sendiri dengan susunan bahan pakan dan kandungan nutrien tersaji pada Tabel 2 .

Alat yang digunakan dalam penelitian ini adalah kandang individu sistem batere sebanyak 50 buah. Kandang untuk anak ayam atau keturunan digunakan kandang breeding sistem litter. Alat lain adalah timbangan digital kapasitas $2 \mathrm{~kg}$ dengan kepekaan 0,1 g, timbangan untuk pakan berkapasitas $5 \mathrm{~kg}$ dan $10 \mathrm{~kg}$, mesin tetas listrik berkapasitas 250 butir, jangka sorong digital, pita ukur dan alat tulis menulis. Jalannya penelitian diawali dengan pengaturan perkawinan dari 5 ekor pejantan dengan 15 ekor betina. Masing-masing pejantan kawin dengan 3 ekor induk. Telur yang dihasilkan diidentifikasi dan diberi kode sesuai tetua (jantan dan induk), dikumpulkan kemudian ditetaskan.

Pengumpulan telur tetas dilakukan setiap hari dan penetasan dilakukan 2 minggu sekali sampai jumlah DOC yang diharapkan dapat terpenuhi yaitu minimal 10 butir perinduk. DOC yang sudah diidentifikasi dengan jelas berdasarkan tetua pejantan dan induk diberi kode, kemudian ditimbang untuk mengetahui berat awal.

\section{Parameter yang diamati}

Parameter yang diamati adalah berat badan. Data diperoleh berdasarkan penimbangan setiap minggu pada masing-masing individu.

\section{Analisis data}

Data penelitian dianalisis dengan menggunakan analisis variansi CRD pola nested design (struktur hierarkis) untuk mendapatkan komponen

Tabel 1. Susunan dan kandungan nutrien pakan pejantan dan induk (the composition and nutrient content of feed and parent group)

\begin{tabular}{|c|c|c|c|c|c|c|c|}
\hline \multirow{2}{*}{ Bahan pakan (feedstuffs) } & \multirow{2}{*}{$\begin{array}{l}\text { Jumlah } \\
\text { (amount) }\end{array}$} & \multicolumn{6}{|c|}{ Kandungan nutrien (nutrient content) } \\
\hline & & $\mathrm{ME}$ & PK & LK & SK & $\mathrm{Ca}$ & $\mathrm{P}$ \\
\hline Jagung (corn) & 60,0 & 2060,0 & 5,4 & 2,28 & 1,50 & 0,012 & 0,132 \\
\hline Bekatul (bran) & 9,0 & 146,7 & 0,75 & 0,71 & 0,74 & 0,009 & 0,117 \\
\hline Konsentrat (consentrat) & 30,0 & 570,0 & 9,90 & 1,50 & 2,40 & 3,600 & 0,450 \\
\hline Mineral & 1,0 & - & - & - & - & 0,325 & 0,100 \\
\hline Top Mix & 0,7 & - & - & - & - & - & - \\
\hline Jumlah (number) & 100,7 & 2776,7 & 16,05 & 4,49 & 4,64 & 3,946 & 0,799 \\
\hline
\end{tabular}

ME: energi termetabolis (metabolizable energy), PK: protein kasar (crude protein), LK: lemak kasar (crude fat), SK: serat kasar (crude fiber), Ca: kalsium (calcium), P: fosfor (phosphor).

Tabel 2. Susunan dan kandungan nutrien pakan keturunan ayam Tolaki (the composition and nutrient content of feed in Tolaki chicken offspring)

\begin{tabular}{lccccc}
\hline \hline \multirow{2}{*}{ Bahan pakan (feed component) } & \multirow{2}{*}{$\begin{array}{c}\text { Proporsi } \\
\text { (proportion) })\end{array}$} & \multicolumn{3}{c}{ Kandungan nutrien (nutrient content) } \\
\cline { 3 - 6 } & 33 & 28,050 & 1112,2 & 0,017 & 0,488 \\
Jagung (corn) & 25 & 72,520 & 1100,5 & 1,150 & 0,192 \\
Tepung ikan (fish meal) & 17,5 & 22,925 & 437,5 & 0,011 & 0,128 \\
Dedak padi (rice bran) & 24,5 & 81,200 & 558,5 & 2,440 & 0,368 \\
Konsentrat layer (consentrat layer) & 100,00 & 20,95 & 3208,7 & 3,618 & 1,176 \\
\hline \multicolumn{1}{c}{ Jumlah (number) } &
\end{tabular}

PK: protein kasar (crude protein), ME: energi termetabolis (metabolizable energy), Ca: kalsium (calcium), P: fosfor (phosphor). 
Tabel 3. Jumlah anak ayam Tolaki hasil lima kelompok perkawinan berdasarkan jenis kelamin yang digunakan dalam penelitian (the number of Tolaki chicks based on sex in five groups)

\begin{tabular}{|c|c|c|c|c|c|c|c|c|c|c|c|c|c|c|c|c|}
\hline \multirow{3}{*}{$\begin{array}{r}\begin{array}{c}\text { Komponen } \\
(\text { component })\end{array} \\
\text { Pejantan }(\text { rooster }) \\
\text { Induk }(\text { hen })\end{array}$} & \multicolumn{15}{|c|}{ Kelompok perkawinan (matting group) } & \multirow{3}{*}{$\begin{array}{c}\text { Total } \\
5 \\
15\end{array}$} \\
\hline & \multicolumn{3}{|c|}{1} & \multicolumn{3}{|c|}{2} & \multicolumn{3}{|c|}{3} & \multicolumn{3}{|c|}{4} & \multicolumn{3}{|c|}{5} & \\
\hline & 1 & 2 & 3 & $\overline{1}$ & 2 & 3 & $\overline{1}$ & 2 & 3 & $\overline{1}$ & 2 & 3 & 1 & 2 & 3 & \\
\hline Keturunan (offspring) & & & & & & & & & & & & & & & & \\
\hline Jantan (male) & 6 & 7 & 7 & 4 & 5 & 4 & 4 & 4 & 5 & 4 & 5 & 5 & 7 & 6 & 5 & 78 \\
\hline Betina (female) & 2 & 3 & 2 & 6 & 6 & 6 & 5 & 5 & 5 & 5 & 4 & 6 & 3 & 4 & 4 & 66 \\
\hline Jumlah (number) & 8 & 10 & 9 & 10 & 11 & 10 & 9 & 9 & 10 & 9 & 9 & 11 & 10 & 10 & 9 & 144 \\
\hline
\end{tabular}

Struktur data ini disusun berdasarkan struktur data hierarkis (Nested design) (this data structure is based on hierarchical data structure).

Tabel 4 . Struktur analisis variansi berdasarkan struktur hirarkis (Nested design) (the analysis of variance based on Nested design)

\begin{tabular}{|c|c|c|c|c|}
\hline $\begin{array}{c}\text { Sumber variansi } \\
\text { (variance source) }\end{array}$ & $\begin{array}{c}\text { Derajat bebas } \\
\text { (degree of freedom) }\end{array}$ & $\begin{array}{l}\text { Jumlah kuadrat } \\
\text { (sum of square) }\end{array}$ & $\begin{array}{l}\text { Rata-rata kuadrat } \\
\text { (mean of square) }\end{array}$ & $\begin{array}{l}\text { Komponen variansi } \\
\text { (variance component) }\end{array}$ \\
\hline $\begin{array}{l}\text { Diantara pejantan } \\
\text { (among males) }\end{array}$ & $\mathrm{v}-1$ & $\sum \mathrm{X}^{2} \mathrm{i} . .-\mathrm{C}$ & $\mathrm{SSjtn} /(\mathrm{v}-1)$ & $\sigma^{2} \epsilon+\mathrm{k} 1 \sigma^{2} \phi+\mathrm{k} 2 \sigma^{2}{ }^{\lambda}$ \\
\hline $\begin{array}{l}\text { Diantara Betina } \\
\text { (among females) }\end{array}$ & $\mathrm{v}(\mathrm{m}-1)$ & $\sum \mathrm{X}^{2} \mathrm{ij} .-\sum \mathrm{X}^{2} \mathrm{i}$. & $\operatorname{SSbtn} / \mathrm{v}(\mathrm{m}-1)$ & $\sigma^{2} \epsilon+\mathrm{k} 3 \sigma^{2} q \sigma^{2} \epsilon$ \\
\hline $\begin{array}{l}\text { Diantara turunan } \\
\text { (among offspring) }\end{array}$ & $\operatorname{vm}(n-1)$ & $\sum X^{2} i j k-\sum X^{2} i j$ & SSket/vm(n-1) & \\
\hline Total & Vmn-1 & & - & $\sigma^{2} \mathrm{~T}=\sigma^{2} \epsilon+\sigma^{2} Q+\sigma^{2} \hat{\sigma}^{2}$ \\
\hline
\end{tabular}

$\sigma \mathrm{S}^{2}:$ komponen variansi jantan (variance component of sire).

$\sigma^{2} \epsilon$ : komponen variansi keturunan/individual error (variance component of offspring).

$\sigma \mathrm{d}^{2}$ : komponen variansi betina (variance component of dam).

varian dari jantan dan betina. Model matematiknya adalah sebagai berikut:

$\mathrm{Y}_{\mathrm{ijk}}=\mu+\mathrm{J}_{\mathrm{i}}+\beta_{\mathrm{ij}}+\varepsilon_{\mathrm{ijk}}$

Keterangan:

$\mathrm{Y}_{\mathrm{ijk}}=$ Nilai pengamatan dari keturunan $=\mathrm{i}$, pakan $=\mathrm{k}$, betina $=\mathrm{j}$ dan jantan

$\mu \quad=$ Rata-rata umum dari pengamatan

$\mathrm{J}_{\mathrm{i}} \quad=$ Pengaruh jantan $(\mathrm{i}=1,2, \ldots 5)$

$\beta_{\mathrm{ij}}=$ Pengaruh betina $(\mathrm{j}=1,2, \ldots 10)$ dalam jantan $(\mathrm{i}=1,2, \ldots 5)$

$\varepsilon_{\mathrm{ijk}}=$ Pengaruh keturunan ke-I untuk masingmasing jantan ke-I dan betina ke-j

\section{Komponen variansi}

Melalui analisis statistik berdasarkan struktur hierarkis (nested design) dihitung komponen variansi diantara jantan, diantara betina dalam jantan dan diantara keturunan dalam betina dan jantan. Perkiraan estimasi genetik berdasarkan komponen variansinya tersaji pada Tabel 4.

\section{Estimasi heritabilitas $\left(\hat{\mathrm{h}}^{2}\right)$}

Estimasi nilai heritabilitas dihitung berdasarkan komponen variansi jantan $\left(\hat{\mathrm{h}}_{\mathrm{s}}^{2}\right)$, komponen variansi betina $\left(\hat{\mathrm{h}}_{\mathrm{d}}^{2}\right)$ dan gabungan komponen variansi jantan dan betina $\left(\hat{\mathrm{h}}^{2}{ }_{\mathrm{s}+\mathrm{d}}\right)$ (Becker,1992), dapat dirumuskan sebagai berikut:

Berdasarkan komponen jantan $\left(\hat{\mathrm{h}}_{\mathrm{s}}^{2}\right)$ :

$$
\hat{\mathrm{h}}_{\mathrm{s}}^{2}=\frac{4 \sigma \mathrm{s}^{2}}{\sigma \mathrm{s}^{2}+\sigma \mathrm{d}^{2}+\sigma^{2} \epsilon}
$$

Berdasarkan komponen betina $\left(\hat{\mathrm{h}}_{\mathrm{d}}^{2}\right)$ :

$$
\hat{\mathrm{h}}_{\mathrm{d}}^{2}=\frac{4 \sigma \mathrm{d}^{2}}{\sigma \mathbf{s}^{2}+\sigma \mathrm{d}^{2}+\sigma^{2} \epsilon}
$$

Berdasarkan komponen jantan dan betina $\left(\hat{\mathrm{h}}^{2}{ }_{\mathrm{s}+\mathrm{d}}\right)$ :

$$
\hat{\mathrm{h}}_{\mathrm{s}+\mathrm{d}}^{2}=\frac{\mathbf{2 \sigma}(\mathbf{s}+\mathbf{d})^{2}}{\boldsymbol{\sigma \mathbf { s } ^ { 2 } + \boldsymbol { \sigma d } ^ { 2 } + \boldsymbol { \sigma } ^ { 2 } \epsilon}}
$$

Keterangan:

$\hat{\mathrm{h}}_{\mathbf{s}}^{2} \quad=$ Estimasi heritabilitas berdasarkan komponen jantan

$\hat{\mathrm{h}}_{\mathrm{d}}^{2} \quad=$ Estimasi heribalitas berdasarkan komponen betina

$\hat{\mathrm{h}} 2\left({ }_{\mathrm{s}+\mathrm{d}}\right)=$ Estimasi heritabilitas berdasarkan komponen jantan dan betina

\section{Hasil dan Pembahasan}

\section{Analisis fenotip ayam Tolaki}

Pengamatan selama 12 minggu penelitian menunjukkan pertumbuhan ayam jantan lebih cepat 
dibandingkan pertumbuhan ayam betina. Berat badan ayam jantan dan betina pada umur 12 minggu masing-masing 342,59 g dan 336,23 g (Tabel 5).

\section{Analisis genetik keturunan ayam Tolaki}

Komponen variansi berat badan. Berdasarkan hasil analisis variansi struktur hierarkis yang digunakan untuk pendugaan nilai heritabilitas. Komponen variansi pejantan $\left(\sigma_{\mathrm{s}}^{2}\right)$ menggambarkan hubungan diantara saudara tiri yang tidak me- munculkan efek induk. Komponen variansi induk $\left(\sigma_{\mathrm{d}}^{2}\right)$ menggambarkan hubungan diantara saudara tiri berdasarkan kelompok induk (Oni et al., 2007). Penyebaran komponen variansi berdasarkan penampilan berat badan menunjukkan komponen variansi pejantan $\left(\sigma^{2} s\right)$ semua bernilai positif dari umur 0-12 minggu. Penyebaran komponen variansi induk $\left(\sigma^{2}\right)$ bernilai positif pada umur $3,4,5$, dan 7 minggu, nilai negatif pada umur $0,1,2,6,8$, sampai 12 minggu.

Tabel 5. Rata-rata berat badan (g/ekor) keturunan ayam Tolaki berdasarkan umur dan jenis kelamin (the mean of body weight Tolaki offspring based on age and sex)

\begin{tabular}{|c|c|c|c|c|c|c|c|c|c|}
\hline \multirow[b]{2}{*}{$0^{\lambda}$} & \multirow[b]{2}{*}{ 오 } & \multirow[b]{2}{*}{$\mathrm{N}$} & \multirow[b]{2}{*}{$d / 9$} & \multicolumn{4}{|c|}{ Umur (minggu) (age (week)) } & \multirow[b]{2}{*}{$\mathrm{X}$} & \multirow[b]{2}{*}{ XII } \\
\hline & & & & II & IV & $\mathrm{VI}$ & VIII & & \\
\hline \multirow[t]{6}{*}{1} & 1 & 8 & $\delta / 6$ & $83,35 \pm 18,30$ & $146,00 \pm 34,50$ & $215,97 \pm 70,30$ & $276,15 \pm 66,13$ & $325,71 \pm 80,23$ & $433,53 \pm 87,86$ \\
\hline & & & $q / 2$ & $75,75 \pm 11,20$ & $142,4 \pm 21,64$ & $190,05 \pm 10,96$ & $231,70 \pm 5,23$ & $351,90 \pm 6,34$ & $332,65 \pm 8,41$ \\
\hline & 2 & 10 & $\delta / 7$ & $74,70 \pm 16,52$ & $127,83 \pm 14,00$ & $194,19 \pm 32,17$ & $266,07 \pm 57,73$ & $320,14 \pm 78,79$ & $397,66 \pm 83,30$ \\
\hline & & & $q / 3$ & $25,27 \pm 2,67$ & $106,87 \pm 12,17$ & $139,47 \pm 3,62$ & $201,60 \pm 56,73$ & $251,97 \pm 68,55$ & $297,5 \pm 73,18$ \\
\hline & 3 & 9 & $\delta / 7$ & $71,23 \pm 8,13$ & $128,37 \pm 9,29$ & $160,01 \pm 33,47$ & & $287,86 \pm 44,91$ & $353,99 \pm$ \\
\hline & & & $+/ 2$ & 54,5 & 82,7 & 197,77 & $188,55=$ & 25 & $306,05 \pm 21,71$ \\
\hline \multirow[t]{6}{*}{2} & 1 & 10 & $\lesssim / 4$ & $69,58 \pm 19,60$ & $126,55 \pm 30,80$ & $178,03 \pm 51,10$ & $219,48 \pm 53,41$ & $272,38 \pm 53,18$ & $335,38 \pm 72,63$ \\
\hline & & & $q / 6$ & $63,58 \pm 13,80$ & $109,18 \pm 18,30$ & $158,68 \pm 23,03$ & $226,22 \pm 52,00$ & $271,20 \pm 67,63$ & $328,13 \pm 71,70$ \\
\hline & 2 & 11 & $\lesssim / 5$ & $70,12 \pm 13,00$ & $107,58 \pm 13,40$ & $159,72 \pm 39,58$ & $227,36 \pm 53,35$ & $282,18 \pm 64,91$ & $327,96 \pm 60,24$ \\
\hline & & & $q / 6$ & $61,78 \pm 21,90$ & $102,58 \pm 30,20$ & $69,53 \pm 67,44$ & $221,37 \pm 74,27$ & $283,38 \pm 86,06$ & $335,52 \pm 99,06$ \\
\hline & 3 & 10 & $\delta / 4$ & & 114 & 56 & 75 & 81 & 354,8 \\
\hline & & & P/6 & & 124,7 & 190, & & & 445,3 \\
\hline \multirow[t]{6}{*}{3} & 1 & 9 & $\delta / 4$ & $80,13 \pm 14,90$ & $121,20 \pm 8,63$ & $166,80 \pm 11,29$ & $215,85 \pm 7,78$ & $253,20 \pm 9,92$ & $65 \pm 22,06$ \\
\hline & & & $q / 5$ & $60,58 \pm 22,70$ & $98,74 \pm 37,78$ & $147,60 \pm 45,73$ & $208,96 \pm 63,02$ & $274,44 \pm 75,85$ & $359,90 \pm 95,17$ \\
\hline & 2 & 9 & $\lesssim / 5$ & $77,58 \pm 15,80$ & $121,73 \pm 15,60$ & $172,10 \pm 16,15$ & $239,48 \pm 11,94$ & $302,30 \pm 34,29$ & $384,53 \pm 75,74$ \\
\hline & & 9 & $q / 4$ & $42,78 \pm 9,06$ & $72,84 \pm 19,91$ & $102,14 \pm 14,39$ & $161,66 \pm 40,17$ & $208,82 \pm 81,20$ & $262,44 \pm 134,18$ \\
\hline & 3 & 10 & $\delta / 5$ & & 42 & 156 & 91 & & $361,34 \pm$ \\
\hline & & & Q $/ 5$ & & 107,68 & 146 , & & & $304,28 \pm 87,27$ \\
\hline \multirow[t]{6}{*}{4} & 1 & 9 & $\delta / 4$ & $58,88 \pm 18,90$ & $111,18 \pm 11,60$ & $158,30 \pm 25,42$ & $235,75 \pm 28,83$ & $303,48 \pm 50,88$ & 1,26 \\
\hline & & & $q / 5$ & $55,82 \pm 13,00$ & $95,66 \pm 12,10$ & $144,18 \pm 17,80$ & $189,46 \pm 17,36$ & $254,46 \pm 45,28$ & $307,12 \pm 67,45$ \\
\hline & 2 & 9 & $\delta / 5$ & $60,22 \pm 7,42$ & $107,08 \pm 11,20$ & $156,80 \pm 27,53$ & $209,46 \pm 27,11$ & $255,42 \pm 46,52$ & $303,82 \pm 58,07$ \\
\hline & & & $q / 4$ & $58,68 \pm 20,70$ & $92,50 \pm 35,22$ & $161,38 \pm 60,70$ & $234,17 \pm 114,36$ & $208,35 \pm 131,35$ & $350,15 \pm 176,99$ \\
\hline & 3 & 11 & $\delta / 5$ & & & & & 5 & $289,30 \pm 27,69$ \\
\hline & & & $\uparrow / 6$ & & 101 & & & & 340,18 \\
\hline \multirow[t]{8}{*}{5} & 1 & 10 & $\delta / 7$ & $60,64 \pm 17,50$ & $104,13 \pm 12,20$ & $158,84 \pm 33,38$ & $206,30 \pm 35,64$ & $266,76 \pm 39,36$ & $323,74 \pm 54,87$ \\
\hline & & & $q / 3$ & $48,43 \pm 14,20$ & $89,17 \pm 28,60$ & $145,53 \pm 43,72$ & $232,40 \pm 84,00$ & $315,33 \pm 110,04$ & $415,60 \pm 159,75$ \\
\hline & 2 & 10 & $\delta / 6$ & $71,55 \pm 11,20$ & $116,55 \pm 20,10$ & $171,35 \pm 30,55$ & $232,27 \pm 37,04$ & $292,73 \pm 80,60$ & $343,82 \pm 96,28$ \\
\hline & & & $q / 4$ & $61,95 \pm 16,70$ & $100,18 \pm 11,70$ & $142,20 \pm 30,70$ & $187,90 \pm 22,98$ & $240,98 \pm 19,61$ & $292,10 \pm 29,04$ \\
\hline & 3 & 9 & $\lesssim / 5$ & & 112 , & & & & $290,12 \pm 52,53$ \\
\hline & & & $9 / 4$ & & & & & & 375,6 \\
\hline & $\mathrm{x}$ & 144 & $\delta / 78$ & & 117 & 169,5 & 228,7 & 284,1 & $342,59 \pm 28,31$ \\
\hline & & & $9 / 66$ &, 73 & 26 & 15 & 24 & 33,80 & $336,23 \pm 46,7$ \\
\hline
\end{tabular}


Pendugaan nilai heritabilitas berat badan. Pendugaan nilai heritabilitas berdasarkan komponen pejantan $\left(\hat{\mathrm{h}}_{\mathrm{s}}^{2}\right)$ terendah pada umur 12 minggu yakni0,27 dan tertinggi pada umur 4 minggu yakni 0,70 . Pendugaan nilai heritabilitas berdasarkan komponen induk $\left(\hat{\mathrm{h}}_{\mathrm{d}}^{2}\right)$ bernilai positif pada umur 1 sampai 5 minggu dan kemudian kembali bernilai positif pada umur 7 minggu. Sedangkan pada umur 0,6 minggu bernilai negatif kemudian pada umur 8 sampai 12 minggu juga bernilai negatif yang berarti penampilan genetik yang bersifat gen aditif tidak tampak. Pendugaan nilai heritabilitas berdasarkan gabungan komponen variansi pejantan dan induk yang merupakan pendugaan nilai heritabilitas

Tabel 6. Komponen variansi genetik berat badan berdasarkan kelompok umur (the genetic variance component of body weight gain based on age group)

\begin{tabular}{crrrr}
\hline \hline \multirow{2}{*}{$\begin{array}{c}\text { Umur (minggu) } \\
(\text { age (week) })\end{array}$} & \multicolumn{4}{c}{ Komponen variansi genetik (genetic variance components) } \\
\cline { 2 - 5 }$\sigma_{\mathrm{s}}^{2}$ & \multicolumn{1}{c}{$\sigma_{\mathrm{d}}^{2}$} & $\sigma^{2}{ }^{2}$ & $\sigma^{2}{ }_{\text {total }}$ \\
\hline 0 & 0,52 & $-0,09$ & 6,96 & 7,39 \\
2 & 4,90 & 0,15 & 45,91 & 50,97 \\
3 & 27,63 & 0,95 & 241,34 & 269,91 \\
4 & 56,68 & 16,35 & 361,09 & 434,12 \\
5 & 104,35 & 28,03 & 462,99 & 595,38 \\
6 & 136,76 & 18,93 & 846,14 & 1001,82 \\
7 & 214,62 & $-36,89$ & 1389,58 & 1572,79 \\
8 & 235,15 & 24,59 & 1679,39 & 1939,14 \\
9 & 303,84 & $-154,74$ & 2350,37 & 2499,46 \\
10 & 337,57 & $-205,34$ & 3442,73 & 3425,34 \\
11 & 322,42 & $-194,11$ & 4216,37 & 4344,68 \\
12 & 559,06 & $-281,18$ & 5392,57 & 5604,68 \\
& 491,23 & $-415,68$ & 7299,77 & 7375,32 \\
\hline
\end{tabular}

$\sigma_{\mathrm{s}}^{2} \quad$ : komponen variansi jantan (variance component of sire).

$\sigma^{2}{ }_{e} \quad$ : komponen variansi keturunan (individual error) (variance component of offspring).

$\sigma^{2}$ total : komponen variansi total (total variance component).

$\sigma^{2}{ }_{\mathrm{d}} \quad$ : komponen variansi betina (variance component of dam).

Tabel 7. Pendugaan nilai heritabilitas berat badan umur 0 sampai 12 minggu (the heritability estimation of body weight on 0 until 12 weeks age)

\begin{tabular}{cccc}
\hline \hline \multirow{2}{*}{ Umur (minggu) (age (week)) } & \multicolumn{3}{c}{ Heritabilitas (heritability) } \\
\cline { 2 - 4 } & $\hat{\mathrm{h}}_{\mathbf{s}}^{2}$ & $\hat{\mathrm{h}}_{\mathrm{d}}{ }_{\mathrm{d}}$ & $\hat{\mathrm{h}}_{(\mathrm{s}+\mathrm{d})}$ \\
\hline 0 & $0,28 \pm 0,29$ & $-0,05 \pm 0,11$ & $0,12 \pm 0,13$ \\
1 & $0,39 \pm 0,33$ & $0,01 \pm 0,08$ & $0,20 \pm 0,23$ \\
2 & $0,41 \pm 0,35$ & $0,01 \pm 0,13$ & $0,21 \pm 0,24$ \\
3 & $0,52 \pm 0,38$ & $0,15 \pm 0,21$ & $0,34 \pm 0,31$ \\
4 & $0,70 \pm 0,45$ & $0,19 \pm 0,13$ & $0,44 \pm 0,25$ \\
5 & $0,55 \pm 0,42$ & $0,08 \pm 0,13$ & $0,31 \pm 0,29$ \\
6 & $0,54 \pm 0,41$ & $-0,08 \pm 0,26$ & $0,23 \pm 0,26$ \\
7 & $0,49 \pm 0,38$ & $0,05 \pm 0,15$ & $0,27 \pm 0,27$ \\
8 & $0,49 \pm 0,38$ & $-0,25 \pm 0,27$ & $0,12 \pm 0,13$ \\
9 & $0,39 \pm 0,33$ & $-0,24 \pm 0,26$ & $0,08 \pm 0,14$ \\
10 & $0,30 \pm 0,28$ & $-0,18 \pm 0,19$ & $0,06 \pm 0,12$ \\
11 & $0,39 \pm 0,33$ & $-0,20 \pm 0,21$ & $0,09 \pm 0,16$ \\
12 & $0,27 \pm 0,26$ & $-0,23 \pm 0,23$ & $0,02 \pm 0,07$ \\
\hline
\end{tabular}

$\overline{\mathrm{h}}_{\mathrm{s}}^{2}$ : komponen pejantan (sire component).

$\hat{\mathrm{h}}^{2}{ }_{(\mathrm{s}+\mathrm{d})}$ : gabungan komponen pejantan dan induk (combination components of sire and dam).

$\hat{\mathrm{h}}_{\mathrm{d}}^{2} \quad$ : komponen betina (dam components). 
individu bernilai positif pada setiap umur dari 0 sampai 12 minggu, dimana nilai heritabilitas yang ditampilkan menunjukkan nilai heritabilitas yang sudah didefinisikan berada di antara 0 sampai 1 . Pirchner cit. Kismiati (1997) menyatakan bahwa komponen variansi pejantan dan induk merupakan pengaruh genetik yang merupakan gabungan pejantan dan induk secara bersama-sama (gen aditif, dominan dan epistasi).

Perkembangan nilai heritabilitas komponen berat badan berdasarkan komponen variansi pejantan, induk, dan gabungan pejantan dan induk tersaji pada Gambar 1.

Nilai heritabilitas berdasarkan komponen pejantan $\left(\hat{\mathrm{h}}_{\mathrm{s}}^{2}\right)$, menunjukkan kemampuan yang lebih tinggi bila dibandingkan dari komponen variansi induk $\left(\hat{\mathrm{h}}_{\mathrm{d}}^{2}\right)$, dan komponen variansi gabungan pejantan dan induk $\left(\hat{\mathrm{h}}_{\mathrm{s}+\mathrm{d}}^{2}\right)$ dari umur 0 sampai 12 minggu, hal ini disebabkan karena dengan meningkatnya umur kemampuan beradaptasi dengan lingkungan semakin baik. Nilai heritabilitas berdasarkan komponen variansi induk $\left(\hat{\mathrm{h}}_{\mathrm{d}}^{2}\right)$, cukup berfluktuasi dan bernilai negatif pada umur $0,6,8$ dan 12 minggu. Nilai heritabilitas komponen variansi gabungan pejantan dan induk $\hat{\mathrm{h}}_{\mathrm{s}+\mathrm{d}}^{2}$ menunjukkan grafik yang berfluktuatif.

Pertambahan berat badan. Komponen variansi pertambahan berat badan pada umur 0-1 sampai 11-12 minggu (Tabel 8). Penyebaran komponen variansi pertambahan berat badan, terlihat bahwa komponen variansi pejantan $\left(\sigma_{s}^{2}\right)$ yang merupakan kemampuan pejantan dalam pendugaan gen aditif dari umur 0 sampai dengan 12 minggu bernilai positif. Penyebaran komponen

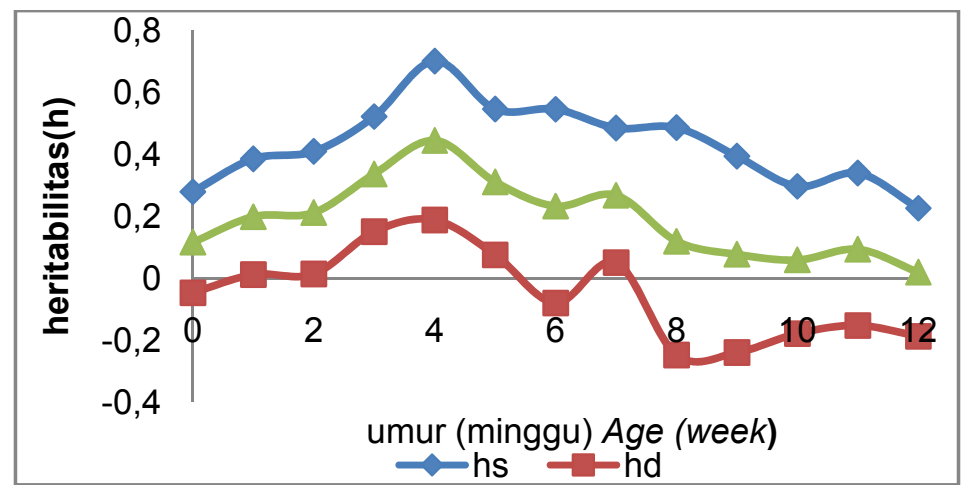

Gambar 1. Pendugaan nilai heritabilitas berat badan umur 0 sampai 12 minggu (the heritability estimation of body weight in 0 untill 12 weeks age).

Tabel 8. Komponen variansi genetik pertambahan berat badan berdasarkan kelompok umur (genetic variance component of body weight based on age group)

\begin{tabular}{ccccc}
\hline \hline \multirow{2}{*}{ Umur (minggu) (age (week)) } & \multicolumn{4}{c}{ Komponen variansi genetik (genetic variance component) } \\
\cline { 2 - 5 }${ }^{2}$ & $\sigma_{\mathrm{s}}{ }^{2}$ & $\sigma_{\mathrm{d}}{ }^{2}$ & $\sigma_{\mathrm{e}}{ }^{2}$ & $\sigma^{2}$ total \\
\hline-1 & 2,47 & $-0,02$ & 29,53 & 31,98 \\
$1-2$ & 10,48 & $-1,32$ & 105,59 & 114,74 \\
$2-3$ & 7,57 & 0,37 & 77,595 & 85,538 \\
$3-4$ & 8,14 & 0,19 & 115,53 & 123,86 \\
$4-5$ & 9,67 & $-8,11$ & 206,38 & 207,93 \\
$5-6$ & 13,36 & $-9,49$ & 281,23 & 285,10 \\
$6-7$ & 16,28 & 9.91 & 416,99 & 443,16 \\
$7-8$ & 4,42 & $-11,29$ & 221,26 & 214,38 \\
$8-9$ & 9,29 & $-23,00$ & 437,44 & 423,72 \\
$9-10$ & 7,29 & 4,55 & 282,87 & 294,705 \\
$10-11$ & 55,06 & $-25,86$ & 396,61 & 425,82 \\
$11-12$ & 15,60 & $-13,53$ & 372,99 & 375,16 \\
\hline
\end{tabular}

$\sigma \mathrm{s}^{2} \quad$ :Komponen variansi jantan (variance component of sire)

$\sigma \epsilon^{2} \quad$ : Komponen variansi keturunan (individual error) (variance component of offspring)

$\sigma^{2}$ total : Komponen variansi total (total variance component)

$\sigma^{2} \quad$ : Komponen variansi betina (variance component of dam). 
Tabel 9. Pendugaan nilai heritabilitas pertambahan berat badan berdasarkan kelompok umur (the heritability estimation of body weight based on age group)

\begin{tabular}{cccc}
\hline \hline Umur (minggu) (age & \multicolumn{3}{c}{ Heritabilitas (heritability) } \\
\cline { 2 - 4 } (week) & $\hat{\mathrm{h}}_{\mathbf{s}}^{2}$ & $\hat{\mathrm{h}}_{\mathrm{d}}^{2}$ & $\hat{\mathrm{h}}_{(\mathrm{s}+\mathrm{d})}^{2}$ \\
\hline $0-1$ & $0,32 \pm 0,23$ & $-0,03 \pm 0,02$ & $0,16 \pm 0,22$ \\
$1-2$ & $0,37 \pm 0,32$ & $-0,05 \pm 0,11$ & $0,15 \pm 0,22$ \\
$2-3$ & $0,35 \pm 0,31$ & $0,01 \pm 0,21$ & $0,19 \pm 0,23$ \\
$3-4$ & $0,26 \pm 0,27$ & $0,06 \pm 0,09$ & $0,13 \pm 0,27$ \\
$4-5$ & $0,19 \pm 0,22$ & $-0,16 \pm 0,09$ & $0,01 \pm 0,21$ \\
$5-6$ & $0,19 \pm 0,27$ & $-0,13 \pm 0,18$ & $0,03 \pm 0,11$ \\
$6-7$ & $0,15 \pm 0,20$ & $0,09 \pm 0,15$ & $0,12 \pm 0,26$ \\
$7-8$ & $0,08 \pm 0,15$ & $-0,21 \pm 0,24$ & $-0,06 \pm 0,18$ \\
$8-9$ & $0,09 \pm 0,15$ & $-0,21 \pm 0,24$ & $-0,06 \pm 0,18$ \\
$9-10$ & $0,10 \pm 0,16$ & $0,06 \pm 0,13$ & $0,08 \pm 0,07$ \\
$10-11$ & $0,52 \pm 0,29$ & $-0,24 \pm 0,18$ & $0,14 \pm 0,16$ \\
$11-12$ & $0,17 \pm 0,19$ & $-0,14 \pm 0,20$ & $0,01 \pm 0,08$ \\
\hline
\end{tabular}

$\widehat{\mathrm{h}}_{\mathrm{s}}^{2}:$ komponen pejantan (sire component)

$\hat{\mathrm{h}}^{2}{ }_{\mathrm{s}+\mathrm{d}}$ : komponen gabungan pejantan dan betina (combination components of sire and dam)

$\hat{\mathrm{h}}_{\mathrm{d}}{ }_{\mathrm{d}}$ : komponen betina (dam components).

variansi betina $\left(\sigma_{\mathrm{d}}^{2}\right)$ yang merupakan genetik dari gen aditif juga oleh gen non-aditif (dominan, epistasi dan interaksi) bernilai negatif pada umur 01 ; 1-2; 4-5; 5-6; 7-8; 8-9; 10-11 dan 11-12 minggu sedang pada umur $2-3 ; 3-4 ; 6-7$ dan 9-10 minggu komponen variansi betina bernilai positif.

Munculnya komponen variansi induk $\left(\sigma_{d}^{2}\right)$ yang negatif pada beberapa periode umur diduga karena faktor lingkungan yang cukup besar variasi yang sulit dideteksi mengakibatkan beragamnya sifat pertumbuhan diantara umur pada keturunan ayam Tolaki (Lariviere et al., 2009). Penyebaran komponen variansi keturunan/individual error $\left(\sigma^{2} \epsilon\right)$ lebih besar dibandingkan komponen variansi pejantan $\left(\sigma_{s}^{2}\right)$ maupun komponen variansi induk $\left(\sigma^{2}{ }_{d}\right)$. Besarnya komponen variansi keturunan $\left(\sigma^{2} \epsilon\right)$ yang merupakan komponen variansi lingkungan merupakan indikasi besarnya pengaruh lingkungan terhadap pertambahan berat badan (Sidadolog, 1998).

Pendugaan nilai heritabilitas pertambahan berat badan. Pada Tabel 9 disajikan nilai heritabilitas pertambahan berat badan umur 0-1 sampai 11-12 minggu. Penyebaran komponen variansi pertambahan berat badan, terlihat bahwa komponen variansi pejantan $\left(\sigma_{\mathrm{s}}^{2}\right)$ yang merupakan kemampuan pejantan dalam pendugaan gen aditif dari umur 0 sampai dengan 12 minggu bernilai positif. Penyebaran komponen variansi betina $\left(\sigma_{d}^{2}\right)$ yang merupakan genetik dari gen aditif juga oleh gen non-aditif (dominan, epistasi dan interaksi) bernilai negatif pada umur $0-1 ; 1-2 ; 4-5 ; 5-6 ; 7-8$;
8-9; 10-11 dan 11-12 minggu sedang pada umur 23 ; 3-4; 6-7; dan 9-10 minggu komponen variansi betina bernilai positif.

Hasil penelitian keturunan ayam Tolaki menunjukkan besarnya pewarisan sifat genetik pertambahan berat badan menunjukkan nilai heritabilitas tinggi berdasarkan gen aditif umur 0-3 minggu dan pada umur 10-11 minggu, nilai sedang pada umur 3-7 minggu, 9-10 dan umur 11-12 minggu, nilai rendah pada umur 7-9 minggu. Pendugaan heritabilitas berdasarkan komponen pejantan (saudara tiri sebapak) paling banyak digunakan dan paling murni untuk ragam genetik aditif diantara metode yang ada, apabila dikerjakan dengan tepat (Adeyinka et al., 2006).

\section{Kesimpulan}

Berdasarkan hasil penelitian yang dilaksanakan terhadap analisis fenotip dan genetik ayam Tolaki pada masa pertumbuhan dapat disimpulkan bahwa pewarisan sifat pertumbuhan berdasarkan komponen variansi pejantan $\left(\hat{\mathrm{h}}_{\mathrm{s}}^{2}\right)$, berdasarkan induk $\left(\hat{\mathrm{h}}_{\mathrm{d}}^{2}\right)$ serta pejantan dan induk $\left(\hat{\mathrm{h}}^{2}{ }_{\mathrm{s}+\mathrm{d}}\right)$ cukup berfluktuasi yang menggambarkan masih luasnya variansi sifat pertumbuhan ayam Tolaki. Kemampuan pewarisan sifat pertumbuhan berdasarkan komponen variansi pejantan $\left(\hat{\mathrm{h}}_{\mathrm{s}}^{2}\right)$ umur 0 sampai 12 minggu dengan nilai heritabilitas tinggi dan bernilai positif. 


\section{Daftar Pustaka}

Anonimus. 2008. Ayam Lokal Indonesia. Available at http://www.sentral ternak.com. Accession date: 19 Juli, 2009.

Becker, A. W. 1992. Manual of Quantitative Genetics. Washington State University, Washington.

Iswanto. 2005. Ayam Kampung Pedaging. PT Agromedia Pustaka. Jakarta.

Lariviere, J. M., C. Michaux, V. Verleyen and P. Leroy. 2009. Heritability estimate and responsemto selection for body weight in the Ardennaise chicken breed. International Journal of Poultry Science 8: 952-956.

Adeyinka, I. A., O. O. Oni, B. I. Nwagu and F. D. Adeyinka. 2006. Genetic parameter estimates of body weight of naked neck broiler chickens. International Journal of Poultry Science 5: 589-592.

Kismiati. 1997. Pengaruh interval inseminasi terhadap performan reproduksi dan heritabilitas pertumbuhan ayam Kedu Hitam. Tesis-S2. Program Pasca Sarjana Fakultas Peternakan, Universitas Gadjah Mada, Yogyakarta.
Nafiu, L. D. dan M. Rusdin. 2007. Studi potensi dan keragaman ayam lokal di Sulawesi Tenggara. Laporan Penelitian. Lembaga Penelitian Unhalu. Unpublished. Kendari.

Nataamijaya, A. G. dan Dwiyanto. 1994. Konservasi ayam Buras (Pelung, Nunukan, Gaok, Kedu Putih Sentul dan Jenis Ayam Kampung Lainnya). Laporan Hasil Penelitian Balai Penelitian Ternak bekerja sama dengan Proyek Pembangunan Penelitian Pertanian Nasional. Badan Penelitian dan Pengembangan Pertanian. Bogor.

Oni, O. O., B. Y. Abubakar, N. I. Dim, O. E. Asiribo and I. A. Adeyinka. 2007. Genetic and phenotypic relationships between Mcnally model parameters and egg production traits. International Journal of Poultry Science 6: 8-12.

Sarwono, B. 2007. Beternak Ayam Buras. Penebar Swadaya. Jakarta.

Sidadolog, J. H. P. 1998. Perbaikan produksi ayam di daerah tropis melalui manipulasi genetik dan pakan. Pidato Pengukuhan Jabatan Lektor Kepala. Fakultas Peternakan Universitas Gadjah Mada. Yogyakarta. 